\title{
Naming God: Exodus 3:14-15 in Augustine's Enarrationes in Psalmos
}

\author{
Michael Glowasky \\ Research Fellow, Vrije Universiteit Amsterdam, Amsterdam, \\ The Netherlands; Booth University College, Winnipeg, Canada \\ Michael_Glowasky@BoothUC.ca
}

\begin{abstract}
Augustine discusses Exodus 3:14-15 on 49 different occasions in his written corpus, 14 of which are found in his Enarrationes in Psalmos. Scholars have been quick to note the importance of God's self-disclosure as I AM in verse 14 for Augustine's conception of the divine as esse. However, far less attention has been paid to the place of verse 15 in Augustine's thought, despite his claim that this verse reveals God's "other name" (aliud nomen): the God of Abraham, Isaac and Jacob. In this article, I discuss four key passages from his Enarrationes in Psalmos - two from the redemptive-historical psalms and two from the psalms of ascent - where Augustine addresses the relationship between the two divine names God reveals to Moses in Exodus 3:14-15. In these four passages, I suggest, Augustine presents temporality and materiality as ongoing necessities for the knowledge of God, despite what he appears to suggest elsewhere.
\end{abstract}

\section{Keywords}

Augustine - revelation - Psalms - temporality - Being

\section{$1 \quad$ Introduction}

It is no secret that Exodus 3:14-15 - the passage where God is revealed to Moses as I AM - played an important role in Augustine's thinking about divine revelation. ${ }^{1}$ In her masterful study of this text in Augustine's thought, Emilie Zum

1 Gilson goes so far to say that, through Augustine's interpretation, this Exodus account "lays down the principle from which henceforth the whole of Christian philosophy will be sus- 
Brunn has pointed out that it serves as a consistent, paradigmatic passage for Augustine's view of divine revelation throughout his life. ${ }^{2}$ Augustine engages in a discussion of this passage 49 times in his written corpus, 14 of which are found in his Enarrationes in Psalmos. ${ }^{3}$ In most of the places where he discusses this passage, he emphasizes the transcendence of God as Being and humanity's utter dependence on God. ${ }^{4}$ He makes the point that, as Being, all created life participates in God, and any creature who willingly turns away from God necessarily turns toward non-being. ${ }^{5}$ God's revelation as Being should also

pended," namely, "that the proper name of God is Being" and that "this name denotes His very essence." E. Gilson, The Spirit of Medieval Philosophy, London, 1936, p. 51. However, it is worth noting that the interpretation of this passage has not been without controversy in the history of Christian thought. In fact, B. Childs commented, "Few verses in the entire Old Testament have evoked such heated controversy and such widely divergent interpretations." The Book of Exodus: A Critical, Theological Commentary, Louisville, 1974, p. 61.

2 E. Zum Brunn, St. Augustine: Being and Nothingness, New York, 1988, pp. 97-119. She comments that, regardless of the context in which Augustine discusses this passage, it "does not change in any way the meaning Augustine, from the De uerareligione up to his last writings, reads into the Name revealed to Moses," which is a demonstration of "the contrast between the Immutable and change" (104). See also R. Teske, To Know God and the Soul: Essays on the Thought of St. Augustine, Washington, DC, 2008, p. 123, who points out that "if there is one aspect of content that Augustine returns to again and again in dealing with the Exodus text, it is divine immutability and eternity." Cf. serm. 6.3.4 (CCSL 41:65); serm. 7.7 (CCsL 41:76).

3 According to Zum Brunn's count, there are 47 instances where Augustine discusses this Exodus passage directly, making his reliance on it unique compared to the preceding patristic tradition. To this list must be added serm. 162C.6 and serm. 341.17, both of which have been discovered after Zum Brunn's list was published. See Zum Brunn, Being, pp. 110, 119.

4 En. Ps. 101(2).10 (CCSL 40:1446); 103(1).3 (CCSL 40:1450). James Swetnam has pointed out that idipsum was a particularly important expression for God in Augustine's thought, for it emphasizes a number of key divine attributes that Augustine often turned to Exod. 3:14 to discuss: simplicity, unity, immutability, eternity. J. Swetnam, "A Note on idipsum in St. Augustine," Modern Schoolman, 30 (1953), pp. 328-31; 328. For an argument that Augustine's use of idipsum as a name for God is apophatic and so not properly a name at all, see J.-L. Marion, "Idipsum: The Name of God According to Augustine," in: Orthodox Readings of Augustine, ed. G.E. Demacopoulos, A. Papanikolaou, Crestwood, N.Y., 20o8, pp. 167-9o. Marion suggests that Augustine does not anticipate any ontological naming of God. In his view, idipsum is a term used by Augustine to designate the radical difference between humanity's existence and God's existence, but, because of its apophatic character, it cannot be a name for God. However, as Teske has pointed out, while it is certainly true that Augustine did not take the name God gives Moses to be a proper name as such, it is a description that applies only to God and is, therefore, a name - not with a connotative meaning, but with a denotative meaning. See Teske, To Know God, p. 123. Cf. C.D. de Vogel, "Ego sum qui sum et sa signification pour une philosophie chrétienne," Revue des Sciences réligieuses (1961), pp. 337-355; 337; and E. Zum Brunn, “La 'Philosophie chrétienne' et l'exégèse d'Exode 3.14," Revue de Théologie et de Philosophie, 19 (1969), pp. 94-105.

5 En. Ps. 1.6 (CCSL 38:16); 38.22 (CCSL 38:371). 
stand as a signal to us that the object of our faith is eternal, and that the I AM is a refuge where we can flee from our time-bound condition. ${ }^{6}$ Furthermore, it proves that God is so far superior to the material and temporal condition of created existence and unquestionably the ruler of all existence, corporeal and incorporeal. ${ }^{7}$ As a result, God's blessings cannot be confused with or compared to the material blessings of this world, for divinity is completely other. ${ }^{8}$

Given this emphasis on divine transcendence, and given the fact that Exodus 3:14-15 does seem to be reflective of his understanding of divine revelation more generally, scholars have, with good reason, continued to read a radical distinction between the temporal and eternal in Augustine's theology of revelation. Roland Teske, for example, has argued that, for Augustine, the record and the events of God's revelation in time are not in and of themselves useful for true knowledge of God, for they speak in corporeal terms. As such, they must first be re-interpreted in a spiritual manner which lends itself to the contemplation of incorporeality. ${ }^{9}$ On the other hand, Frederick Van Fleteren has made the case that the historical plane is, in fact, "most important" for Augustine's theology of revelation..$^{10}$ However, when he goes on to explain how this works in Augustine's actual practice, Van Fleteren concedes that very often - in the entire psalter, for example - knowing God is a matter of spiritual contemplation, while the temporal quality of divine revelation remains largely overlooked. ${ }^{11}$

More recently, Michael Cameron has claimed that Augustine valued God's temporal revelation for the sake of the "little ones" in his flock, the "simple-minded" who cannot contemplate eternal realities. ${ }^{12}$ In contrast to Van Fleteren, who holds that Augustine spiritualized the Psalms, Cameron maintains that Augustine's Enarrationes address people of "simple faith," and so exemplify Augustine's focus on the "earthy, historically dense stories and images." ${ }^{13}$ For Cameron, therefore, Augustine is concerned with God's revelation in history, but that concern is merely intended "to stimulate pastorally the initial steps of faith" of the simple-minded in his audience, while those of su-

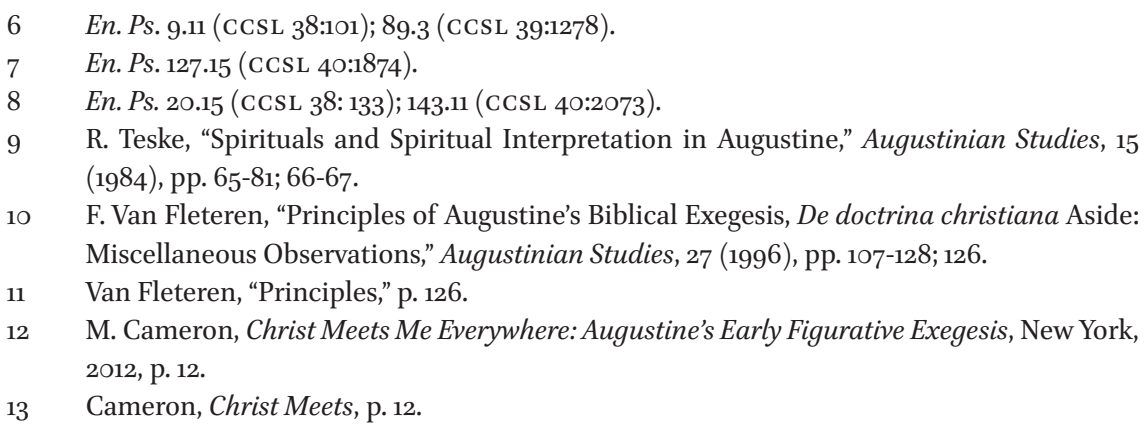


perior intellectual ability can contemplate eternal things directly. ${ }^{14}$ Thus Cameron draws the sharp distinction between different "grades" of the knowledge of God for Augustine, the lowest being those who rely on history and the highest being those who can contemplate spiritual realities without resorting to material images. ${ }^{15}$

Though very different in many significant respects, these three positions serve to illustrate the fact that the predominant view of Augustine's theology of revelation is that true knowledge of God is reserved for those with the intellectual capacity to contemplate immaterial realities. On this reading, there is a sharp distinction between knowledge of God as eternal Being and knowledge of God in temporal and material terms through salvation history. As a result, God's self-disclosure in time is seen either as irrelevant or as second-rate for Augustine, reserved only for minds which prove to be too weak to contemplate eternity. The obvious implication is that God is only truly known despite salvation history, and if what historical realities relate to the human mind can even be called knowledge of God, it is certainly knowledge in some lesser sense.

However, drawing such a sharp line of distinction in Augustine's thought between God's eternity and God's revelation in time comes at the expense of recognizing how, at times, Augustine holds the two together. This is especially the case in four of his Enarrationes (104, 121, 130, and 134), where he discusses Exodus 3:14-15 in some detail. I suggest that, when carefully considered, Augustine's comments on these four psalms add a level of complexity to the common renderings of his theology of revelation by emphasizing the ongoing necessity of God's temporal revelation for any knowledge of God. My goal in this essay is not to challenge the consensus that Augustine valued eternal, spiritual realities over mutable creation. Rather, I simply want to show that things are not always as neat in Augustine's thought as that consensus makes it seem. By drawing attention to these largely overlooked passages in the Enarrationes, this paper will complicate common readings of Augustine's theology of revelation by suggesting that these four enarrationes present history and materiality as ongoing necessities for the knowledge of God.

\section{$2 \quad$ Redemptive-Historical Psalms}

The group of psalms that modern biblical scholars have classified as "redemptive-historical" usually consists of six psalms: 8, 77(78), 104(105), 105(106),

\footnotetext{
14 Cameron, Christ Meets, p. 17.

15 Cameron, Christ Meets, p. 62.
} 
134(135), 135(136)..$^{16}$ They are grouped together because each of them focuses specifically on God's saving acts in Israel's history. In his enarrationes on psalms 104(105) and 134(135), Augustine is prompted by the psalmist's reference to the exodus to pause and reflect on the calling of Moses in Exodus 3. In both cases, Augustine begins by noting that, at first glance, there appear to be two levels of God's revelation discernable in Exodus 3:14-15. In verse 14, God is revealed as "I am who am," but, then in verse 15, God states: "I am the God of Abraham, the God of Isaac, and the God of Jacob." Augustine observes that it seems as if God is revealed under two distinct names, one which speaks of eternal being and the other which points to activity in time throughout human history. ${ }^{17}$

At first, Augustine seems to suggest that this is, indeed, what is going on. He imagines for his audience what God might say if questioned about having two names:

Do you think he would reply, giving you his reason like this? "When I said, I AM WHO AM, it was true, but you could not understand it. Yet when I say, I am the God of Abraham, the God of Isaac, and the God of Jacob, that too is true, but you can take it in. The name I AM WHO AM is suitable to me, but the name the God of Abraham, the God of Isaac, and the God of Jacob is adjusted to your comprehension. If you fall back defeated from what I am to myself, understand what I am for you."18

Because the concept of absolute Being is so difficult for people to take in, Augustine reasons that it makes sense to think that God "mercifully accommodated his grace to humanity by revealing his name in these [temporal] terms." ${ }^{19}$ These comments seem to indicate that, for Augustine, God has two different names. The first name, I AM (esse), is God's true name, while the "other name" (aliud nomen), God's temporal name, is adjusted to the comprehension level of those who are unable to comprehend Being as such. ${ }^{20}$ It would appear, on the surface at least, that God does have two names and that knowledge of these names corresponds to two levels of intellectual ability.

16 See, for example, T. Longman III, How to Read the Psalms, Downers Grove, 1988, pp. 32, 35. I follow the LXx and Vulgate numbering throughout this article.

17 En. Ps. 104.4 (CCSL 40:1493); 134.6 (CCSL 40:1940).

18 En. Ps. 134.6 (CCSL 40:1940). Throughout this article, I follow the translation of M. Boulding, Expositions of the Psalms, 3 vols., ed. by J. Rotelle, M. Boulding, and M. Fiedrowicz, Hyde Park, 2000-2004. For a reading which emphasizes two distinct levels of knowledge of God here, see B. Studer, "History and Faith in Augustine's De Trinitate," Augustinian Studies, 28 (1997), pp. 7-5o.

19 En. Ps. 104.4 (CCSL 40:1493).

$20 \quad$ En. Ps. 134.6 (CCSL 40:1940). 
But Augustine immediately goes on to say that this is not the case. Despite the fact that they seem to function as two different names, and that Augustine himself even refers to them as two names, he is adamant that they are, in fact, a single name. To make his point, he appeals to the final line of verse 14: " $[\mathrm{T}] \mathrm{o}$ exclude any human anxiety that this [God's revelation as the God of Abraham, Isaac and Jacob] might possibly be his temporal name, but not his eternal name, he reassured us that he is leading us from temporal realities to eternal life. This is my name forever, he said."21 Because God explicitly tells Moses that being the God of Abraham, the God of Isaac, and the God of Jacob is the divine name forever, Augustine reasons that it would be incorrect to reduce this "other name" to a mere temporal accommodation. God's temporal name is God's eternal name, and God's eternal name is God's temporal name.

There appears to be a tension in Augustine's thought here. On the one hand, he is deeply concerned to maintain the eternality and immutability of the divine essence and thus God's transcendence. But, on the other hand, he wants to affirm the validity of God's temporal revelation as truly revealing who God is. The solution he comes up with to resolve this tension in the case of both psalm 104(105) and psalm 134(135) is to introduce an additional factor: human limitation. Augustine makes this point most clearly in his exposition of psalm 134(135). He asks his audience to attempt to understand what God said to Moses in verse 14, where God is revealed as Being, and then to contemplate Being itself. Augustine concludes that this is impossible, not just for the simple-minded, but even for himself: "If there is someone, as is quite possible, with mental capacity greater than mine (acie mentis fortior me), who can keep the gaze of his heart fixed on that which is (in eo quod est), let him offer praise as he can well do, and let him praise how unable we are to do it (laudet ille ut potest, et quomodo nos non possumus, laudet)."22 While Augustine appears to not completely rule out the possibility of someone contemplating Being without turning to history here, he admits that he himself cannot do it. Given the context, in which Augustine is trying to hold together God's eternity and temporal revelation, his comments about the possibility of circumventing history is almost certainly a matter of rhetorical flourish. This is further reinforced by the fact that he goes on to comment that the psalmist is calling his readers to do the impossible, for humans "lack the capacity to contemplate him [God] in himself." ${ }^{23}$ He goes on, "One day, perhaps, we shall be able to contemplate him,

\footnotetext{
$21 \quad$ En. Ps. 134.6 (CCSL 40:1940). Cf. Conf. 12.15 (CCSL 27:223).

22 V. Bourke takes this passage as an indication of the existential dimension of Augustine's conception of God as esse in "Augustine on the Psalms," in: Augustine: Biblical Exegete, ed. F. Van Fleteren, J.C. Schnaubelt, New York, 2001, p. 6o-61. 
when our hearts have been so purified by faith that they can at last rejoice in the truth. But now, while we cannot see him, let us gaze upon his works." ${ }^{24}$

It might seem as if, at this point, one might reasonably conclude, along with Colin Gunton, that Augustine renders any knowledge of God as, ultimately, impossible. ${ }^{25}$ If God's true name is the eternal name, and if that name is beyond all human comprehension, it would seem that humanity is unable to know God at all. Gazing upon the works of God, then, would offer an approximate, but not genuine, knowledge of God. But, in this case at least, Augustine's emphasis on divine transcendence should not be taken as a denigration of divine revelation or the knowability of God. On the contrary, Augustine's insistence that human beings lack the capacity to contemplate God as I AM is an attempt to make way for the necessity of temporal revelation and to rule out any notion that knowledge of God is dependent on human ability. This is why he immediately goes on to explain that it is through God's revelation in time as the God of Abraham, the God of Isaac and the God of Jacob, that human beings are able to come to genuine knowledge of the divine. God's temporal name is the means by which humans come to the knowledge of God as I AM.

To demonstrate how this works, Augustine draws attention to the psalmist's construction of psalm 104(105) and 134(135). In each of these psalms, the psalmist begins to recount God's salvific work in history immediately after exhorting his readers to seek God in eternity. Psalm 104(105) begins by exhorting readers to praise God and to seek God's presence in the first four verses. But in verse 5 there is a distinct shift in which the psalmist "descends to words and content we can more easily grasp," by which, Augustine asserts, "he nourishes our weak love by nursing us on the temporal wonders wrought by God."26 A similar shift takes place in psalm 134(135) where, after the first seven verses, the psalmist recounts God's redeeming work in the exodus. By turning to history, the psalmist seeks to draw readers into the loftier knowledge depicted in

\footnotetext{
24 En.Ps. 134. 5 (CCSL 40:1940).

25 One of the objections Colin Gunton voiced against Augustine was that he conceived of divine revelation as essentially unmediated. According to Gunton, God is essentially unknowable in Augustine's system because the eternal never touches the temporal. He goes so far as to state: "at least one of the causes of Western atheism is a theological tradition which encourages thought in the essential unknowability of God" in such a way as to "suggest or teach that the unknowable God can in no way make himself known." C. Gunton, "Augustine, the Trinity and the Theological Crisis of the West," Scottish Journal of Theology, 43 (1990), pp. 33-58; 33. For a clear summary of Gunton on this point, and a rebuttal to him, see B.G. Green, Colin Gunton and the Failure of Augustine, Eugene, 2011, p. 183. Cf. S.N. Williams, Revelation and Reconciliation: A Window on Modernity, Cambridge, 1996, p. 7 .

26 En. Ps. 104.3, 4 (CCSL 40:1493).
} 
the praise of the first seven verses. For Augustine, the structure of these psalms mirror the pattern of divine revelation depicted in Exodus 3:14-15. It is God's revelation through activity in time that makes the divine knowable in eternity.

According to En. Ps. 104 and 134, Exodus 3:14-15 is not just the basis on which Augustine identifies God as esse; it also provides him with the pattern for understanding God's self-disclosure and for coming to the knowledge of God as I AM. While Augustine stops short of explicitly stating that temporal revelation is the necessary means for temporally-conditioned humanity to know God as Being, he does seem to indicate in his comments on these two psalms that knowledge of God as I AM is impossible without the aid of God's revelation in salvation history. If this is true, temporal revelation cannot be irrelevant or even a second-rate means of coming to the knowledge of God.

\section{The Psalms of Ascent}

The Psalms of Ascent, the title given by biblical scholars to psalms 119-133 (120134), have long been recognized as a fifteen-psalm unit because each psalm contains the inscription "Song of Ascents" in its title. Early Christians generally approached them as facilitating the gradual ascent to the life of God. ${ }^{27}$ Once again, Augustine discusses Exodus 3:14-15 in his comments on two of these psalms, 121(122) and 130(131).

In his exposition of psalm 121(122), it is Augustine's discussion of the character of the spiritual Jerusalem that prompts his consideration of the Exodus passage. After commenting that the spiritual Jerusalem shares in the being of God (cuius participatio eius in idipsum), Augustine guides his audience into an inquiry of I AM, which is to say, of Being (esse) itself:

Now, brothers and sisters, if anyone can apply the keen edge of the mind, if anyone can lay aside the murk of the flesh, if anyone can cleanse the eye of the heart, let him or her look up and see. What is idipsum? It is simply idipsum, Being-Itself. How can I say anything about it, except that it is Being-Itself? Grasp it if you can, brothers and sisters, for whatever else I may say, I shall not have defined Being-Itself. All the same, let us attempt to direct the gaze of our minds, to steer our feeble intelligence, to thinking about Being-Itself, making use of certain words and meanings that have some affinity with it. ${ }^{28}$

27 On the Psalms of Ascent in Augustine's thought, see G. McLarney, St. Augustine's Interpretation of the Psalms of Ascent, Washington, DC, 2014. 
So far, Augustine is being faithful to what one would expect to find within the ascent motif. He attempts to define idipsum as "that which Is," "the eternal," and "I am who am." ${ }^{29} \mathrm{He}$ hints in the above passage that the way to contemplate being is to "lay aside" the murk of the flesh and to attempt to "direct the gaze of our minds" in such a way as to be "thinking about Being-Itself."

But then he comments to his audience, "You cannot take it in, for this is too much to understand, too much to grasp. Hold on instead to what he whom you cannot understand became for you." ${ }^{30}$ Rather than continuing to pursue an intellectual ascent to the contemplation of Being, Augustine turns to the plane of history, encouraging his listeners to hold on to Christ's flesh (as a metaphor for materiality and temporality), for "God speaks to weak people, telling them that this Word which was made flesh and lived among us came from the stock of Abraham." ${ }^{31}$ Augustine makes no distinction between the weak and the strong in this passage, instead referring to everyone in his audience as "weak." So when he goes on to explain that God's self-revelation is accommodated for those who cannot contemplate God as Being, the implication is that this includes all of humanity. Offering his audience a gloss on the second part of the Exodus text, Augustine explains God's accommodation: "I [God] am coming down to you, because you cannot come up to me. I am the God of Abraham, the God of Isaac and the God of Jacob." ${ }^{32}$ God accommodates divine revelation to the constraints of the creature's condition, such that the contemplation of divine Being begins with a consideration of salvation history.

In a similar fashion, we find Augustine emphasizing the importance of history for the knowledge of eternal Being in psalm $130(131)$. Verse 2 reads:

O Lord, my heart is not exalted, nor my eyes raised high. Never have I walked in great matters, or in wonders above me. If I was not lowly in mind, but spiritually high-flown, may retribution come upon my soul as on a baby in its mother's arms that is torn away from its milk.

As he turns to discuss the final clause of this verse, Augustine brings up an interpretation, which he says other expounders have offered before him, where this passage is used to refer to those who refuse to mature spiritually but would rather continue suckling at their mother's breast. ${ }^{33}$ According to this interpretation, when the psalm speaks of a baby being torn away from its mother's milk, it is referring to those who have not been weaned from temporal things

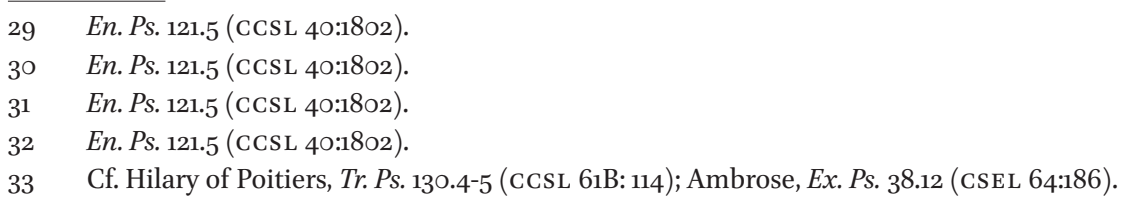


and so refuse to lift their hearts from the temporal realm, beyond even the changes within the human soul, to the eternal, immutable reality of Being. Augustine characterizes this interpretation in this way: "Unless the soul, therefore, transcends even its own experience of itself, it will not see that God is Absolute Being. As he said, I AM WHO AM." ${ }^{34}$ On this reading, the knowledge of God as Absolute Being is only possible by overcoming the barrier of one's own temporality.

However, while Augustine admits that such an interpretation does not directly oppose the Christian faith, it is not the interpretation he himself would prefer. ${ }^{35}$ Instead of emphasizing the necessity for one to move from the spiritual milk of history to the solid food of eternity, Augustine prefers to emphasize the importance of the milk itself for the maturation process:

When a child is growing well and is weaned, that is good for it, but if this is done when it is still a baby in arms, it is harmful. We therefore need to be careful, brothers and sisters, and very cautious lest anyone be weaned prematurely. Every growing child is weaned from milk, but no one should be deprived of milk while still in his mother's arms. A baby is first carried in its mother's womb until it is ready to be born and then carried in her arms until it is grown. While still in her arms it needs milk. ${ }^{36}$

The shift he is making is subtle but significant. Rather than viewing temporality as a barrier to be overcome, Augustine encourages his audience to consider God's temporal revelation as the means to the knowledge of God in eternity. By doing this, he says to his audience, "your strength will increase, and you will see what you were unable to see and take in what you previously could not."37 It is telling that, even in a context that would warrant an emphasis on a Neoplatonic styled ascent to the contemplation of Being, Augustine is sure to emphasize the importance of temporal revelation for the knowledge of God.

Augustine's introduction to the psalms of ascent as a whole reflects further his insistence that the knowledge of God in eternity comes by embracing God's descent into human history. Augustine recalls how, when two of Jesus' disciples began to talk about sitting on his right and left in heaven, he rebuked them (Matt. 20:22), explaining that they were "ambitious for an over-hasty ascent," and that they "gave no thought to the route of humility." ${ }^{38}$ Once again,

\footnotetext{
34 En.Ps. 130.12 (CCSL 40:19o6).

35 En.Ps. 130.13 (CCSL 40:19o6).

36 En.Ps. 130.13 (CCSL 40:1906).

37 En. Ps. 130.13 (CCSL 40:1906).

38 En.Ps. 119.1 (CCSL 40:1785).
} 
Augustine shies away from the language of ascent in favour of the language of maturation. He explains that the Psalms of Ascent describe the same maturation process that takes place in coming to know Christ, in which God took on human flesh in order to lead us through that flesh to the contemplation of divinity:

He [Christ] is solid food, but you can only take milk; and so he who was solid food was processed through flesh to reach your palate. A mother does this: she eats solid food and processes it through her flesh to pass it on to her baby in the form of milk; similarly, the Word, the Lord, the food of angels, was made flesh. ${ }^{39}$

As an infant receives the nutrients of solid food through its mother's milk, Augustine advises his audience to set their sights on God's historical revelation, of which the incarnation is central: "Suck what he became for you," Augustine exhorts, "and you will grow toward what he is."

\section{Conclusion}

This brief look at how Augustine uses one of the most important and clearest passages of God's self-revelation in the Old Testament in his Enarrationes shows that history and materiality are not as irrelevant in his theology of revelation as is often assumed. In fact, in these four enarrationes, Augustine seems to suggest that God's revelation in salvation history is the necessary means to the contemplation of God in eternity. This is not only the case in his comments on the psalms which themselves emphasize God's historical revelation, but it is also found in his expositions of the psalms of ascent. In these four passages, therefore, what appears to be two distinct levels of divine revelation in Exodus 3:14-15, is actually a depiction of the pattern by which all people come to the knowledge of God.

39 En.Ps. $119 \cdot 2(\operatorname{CCSL} 40: 1785)$.
40 